ISSN 1392-3196 / e-ISSN 2335-8947

Zemdirbyste-Agriculture, vol. 106, No. 4 (2019), p. 377-382

DOI 10.13080/z-a.2019.106.048

\title{
Mycobiota in bee pollen collected by different types of traps
}

\author{
Jolanta SINKEVIČIENĖ, Algirdas AMŠIEJUS \\ Vytautas Magnus University, Agriculture Academy \\ Studentų 11, Akademija, Kaunas distr., Lithuania \\ E-mail: jolanta.sinkeviciene@vdu.lt
}

\begin{abstract}
The aim of this study was to determine the impact of different types of bee pollen traps on the microbiological contamination of pollen influenced by the duration of pollen retention in traps. A total of 96 bee pollen samples were analyzed. The total count of microorganisms in the bee pollen during the study period varied from 4.5 to 19.3 $\times 10^{3} \mathrm{cfu} \mathrm{g}^{-1}$. Moisture content in the pollen was optimal for the growth and proliferation of microorganisms. In the pollen, the following most common 7 genera of fungi were found: Penicillium, Fusarium, Alternaria, Acremonium, Cladosporium, Mucor and Rhizopus. A study of the mycobiota of pollen collected from four different traps showed that the total number of microorganisms varied depending on the type of trap and pollen retention period. The pollen collected after 9 hours retention in traps was less contaminated with the microorganisms than that collected after 24 and 48 hours. The count of mycobiota was the lowest $\left(4.5 \times 10^{3} \mathrm{cfu} \mathrm{g}^{-1}\right)$ in the pollen sampled after 9 hours retention from high-bottom traps compared to other types of traps. The highest contamination $\left(19.3 \times 10^{3} \mathrm{cfu} \mathrm{g}^{-1}\right)$ of fresh bee pollen was found after 48 hours in traps with thermo chambers. Fungal contamination was the higest in the bee pollen collected by traps mounted at hive entrance after 9 and 48 hours, respectively 124 and 150 units. The Penicillium fungi dominated the pollen in traps with thermo chambers, Fusarium - in low-bottom, Alternaria - in the pollen of traps mounted at beehive entrance.
\end{abstract}

Key words: bee pollen, contamination, fungi, microorganisms, traps.

\section{Introduction}

Bee pollen is considered to be one of the most complete food items in nature (Petrovic et al., 2014). Pollen contains about 200 different substances, including proteins, carbohydrates, flavonoids, enzymes, trace elements, and numerous amino acids and vitamins (Deveza et al., 2015; Kieliszek et al., 2018).

An important issue concerning the criteria of pollen quality is its purity and microbiological safety (Deveza et al., 2015). It seems that the most critical step is the removal of pollen from traps. Long-term pollen retention in traps can cause an increase in humidity, which favours the growth of microorganisms (González et al., 2005; Estevinho et al., 2011). Microscopic fungi grow when water activity ranges from 0.61 to 1 , but can sometimes grow on a very dry surface (Whitefield, 1998; Jay, 2007). Bee pollen is reported as a substrate that stimulates the production of mycotoxins (Medina et al., 2004), if a beekeeper does not provide adequate and prompt drying (Garcia-Villanova et al., 2004). The main mycotoxin-producing genera are Aspergillus, Fusarium and Penicillium, which can cause acute or chronic poisoning - mycotoxicosis (Estevinho et al., 2011; Petrovic et al., 2014). Aspergillus and Penicillium in the trapped pollen present a potential risk for human health (Nardoni et al., 2016). Alternaria and Cladosporium are considered to be hazardous moulds (Kačaniova et al., 2011). Microscopic fungi are very common in nature and have spores resistant to various environmental factors. They can both contaminate pollen and be present in honey together with pollen (Popa et al., 2009). A number of studies (Brindza et al., 2010; Kačaniova et al., 2011; Petrovic et al., 2014) have revealed significant contamination levels of bee pollen by microorganisms. Therefore, it is very important to find out the presence and quantity of microscopic fungi that dominate pollen, as some of these fungi are potential mycotoxin producers, while others, although not producing toxic metabolites can cause allergic reactions (Estevinho et al., 2011).

Pollen collection is a very thorough job that needs to be done every day. It seems that the most important stage is pollen removal from traps (Gonzáles et al., 2005). If pollen is not removed from traps for a day, this poses a risk of fungal contamination, because there is a lack of research not only regarding the initial fungal contamination of pollen, which can be influenced by different pollen traps, but also regarding the safest

Please use the following format when citing the article:

Sinkevičienè J., Amšiejus A. 2019. Mycobiota in bee pollen collected by different types of traps. Zemdirbyste-Agriculture, 106 (4): 377-382. DOI 10.13080/z-a.2019.106.048 
duration of pollen storage in them. As is well known to the authors of this study, few researchers have investigated the microbial contamination of a dried pollen substrate.

Therefore, due to the lack of information, the aim of this study was to determine the impact of different pollen traps on the fungal contamination depending on the duration of pollen retention in traps.

\section{Materials and methods}

Bee pollen samples. In June-July 2018, a total of 96 pollen samples were colected from beekeepers in Central Lithuania. Bees had collected pollen from different plant species.

Types of traps. The pollen was collected using four types of traps (factor A): 1) high-bottom trap, mounted inside hives, $40 \mathrm{~cm}$ above the bottom; 2) lowbottom trap, mounted inside hives, $15 \mathrm{~cm}$ above the bottom; 3) front trap at the hive entrance, mounted in front of the entrance on the outside of a hive; and 4) front trap at the hive entrance with a thermo chamber, mounted in front of the entrance on the outside of a hive.

Pollen retention periods. The pollen from the same traps was removed at different retention times (factor B): after 9 hours (32 samples), after 24 hours (32 samples) and after 48 hours (32 samples). Having removed the pollen on the same day, moisture content $(\%)$ of fresh bee pollen was determined and after 12 hours microbiological studies were carried out. The samples were placed in sterile plastic bags, vacuumed, packed and stored at $-15^{\circ} \mathrm{C}$ temperature prior to microbiological analysis.

Determination of moisture content. Moisture content was determined by drying $5 \mathrm{~g}$ of a sample in an oven at $105^{\circ} \mathrm{C}$ temperature until constant weight.

Isolation and morphological characterization of microscopic fungi. The dilution plate technique was used for isoliation of fungi from the samples. Microscopic fungi were isolated by adding $10 \mathrm{~g}$ of ground pollen to $90 \mathrm{ml}$ of physiological saline $(\mathrm{NaCl}) 8.5 \mathrm{~g} \mathrm{~L}^{-1}$ and shaken in a shaker for $15 \mathrm{~min}$. A series of dilutions was prepared from the resulting suspension. Suspensions of $1 \mathrm{ml}$ of $10^{-2}$, $10^{-3}$ and $10^{-4}$ were poured into Petri dishes, before the potato dextrose agar (PDA) medium was added on top. All assays were performed in triplicate. The Petri dishes with cultures were incubated in a thermostat at $26 \pm 2{ }^{\circ} \mathrm{C}$ for 5-7 days, and for the isolation of yeast the plates with cultures were maintained for 2-4 days. Grown fungi were counted and evaluated as colony-forming units per gram $\left(\mathrm{cfu} \mathrm{g}^{-1}\right)$ in bee pollen. The distinct fungal species were identified based on morphological identification keys of Pitt and Hocking (2009).

Statistical analysis of data was performed by the analysis of variance (ANOVA), software Statistica (StatSoft Inc., USA). Research data were statistically evaluated by one-way and two-way ANOVA of quantitative methods of evidence (Raudonius, 2017). Significant interaction between the investigated factors was established and means of main effects are not presented.

\section{Results}

After 9 hours, the moisture content in the pollen of the tested samples, ranged from $16.21 \%$ to $37.70 \%$ (Table 1). The highest moisture content in bee pollen was found in low-bottom traps. After 24 hours, the moisture content in the pollen ranged from $17.06 \%$ to $25.58 \%$, and the highest moisture content was found in high-bottom traps $(25.58 \%)$. After 48 hours, the moisture content ranged from $14.60 \%$ to $18.35 \%$. The highest moisture content in pollen was recorded in traps mounted at beehive entrance equipped with thermo chambers.

Table 1. Moisture content (\%) of the bee pollen collected by different traps

\begin{tabular}{lccc}
\hline \multicolumn{1}{c}{$\begin{array}{c}\text { Type of trap } \\
\text { (factor A) }\end{array}$} & \multicolumn{3}{c}{ Pollen retention period (factor B) } \\
\cline { 2 - 4 } & 9 hours & 24 hours & 48 hours \\
\hline High-bottom & $18.27 \mathrm{~d}$ & $25.58 \mathrm{~b}$ & $14.60 \mathrm{e}$ \\
Low-bottom & $37.70 \mathrm{a}$ & $21.42 \mathrm{c}$ & $16.86 \mathrm{de}$ \\
At hive entrance & $16.21 \mathrm{de}$ & $17.06 \mathrm{de}$ & $15.11 \mathrm{e}$ \\
At hive entrance with a thermo chamber & $18.34 \mathrm{~d}$ & $21.92 \mathrm{c}$ & $18.35 \mathrm{~d}$ \\
\hline
\end{tabular}

Note. Means not sharing common letters are significantly different at $P<0.05$.

The microbiological analysis of pollen condition showed that it varied depending on the type of traps and the duration of pollen retention in them. The total number of microorganisms in pollen during the study period ranged from 4.5 to $19.3 \times 10^{3} \mathrm{cfu} \mathrm{g}^{-1}$ (Table 2 ).
The pollen removed from traps after 9 hours had the lowest microbiological contamination compared to other hours of the study. The total amount of microorganisms in the samples fluctuated from $4.5 \times 10^{3}$ to $9.5 \times 10^{3} \mathrm{cfu} \mathrm{g}^{-1}$ with the average moisture content of

Table 2. Microbial contamination $\left(\mathrm{cfu} \mathrm{g}^{-1}\right)$ of the bee pollen collected by different traps

\begin{tabular}{|c|c|c|c|}
\hline \multirow{2}{*}{$\begin{array}{l}\text { Type of trap } \\
\text { (factor A) }\end{array}$} & \multicolumn{3}{|c|}{ Pollen retention period (factor $\mathrm{B}$ ) } \\
\hline & 9 hours & 24 hours & 48 hours \\
\hline High-bottom & $4.5 \times 10^{3} \mathrm{~g}$ & $4.9 \times 10^{3} \mathrm{fg}$ & $5.0 \times 10^{3} \mathrm{f}$ \\
\hline Low-bottom & $7.0 \times 10^{3} \mathrm{e}$ & $8.4 \times 10^{3} \mathrm{~d}$ & $13.2 \times 10^{3} \mathrm{~b}$ \\
\hline At hive entrance & $5.7 \times 10^{3} \mathrm{f}$ & $6.6 \times 10^{3} \mathrm{e}$ & $6.7 \times 10^{3} \mathrm{e}$ \\
\hline At hive entrance with a thermo chamber & $9.5 \times 10^{3} \mathrm{c}$ & $9.6 \times 10^{3} \mathrm{c}$ & $19.3 \times 10^{3} \mathrm{a}$ \\
\hline
\end{tabular}

Note. Means not sharing common letters are significantly different at $P<0.05$. 
$22.6 \%$. Comparison of the types of traps indicated that the lowest number of microorganisms after 9 hours in the high-bottom traps comprised $4.5 \times 10^{3} \mathrm{cfu} \mathrm{g}^{-1}$. The pollen collected from traps mounted at the hive entrance, as compared to the low-bottom ones and traps with thermo chambers, was also found to have lower microbial contamination $-5.7 \times 10^{3} \mathrm{cfu} \mathrm{g}^{-1}$. The highest amount of microorganisms was found in the traps with thermo chambers.

The pollen removed from high-bottom traps after 24 hours showed the lowest level of microorganism contamination $-4.9 \times 10^{3} \mathrm{cfu} \mathrm{g}^{-1}$. The total number of microorganisms in the pollen collected by low-bottom traps was not the highest; it comprised $8.4 \times 10^{3} \mathrm{cfu} \mathrm{g}^{-1}$; however, having compared this amount of microorganisms with that of the pollen removed on the same day, the highest increase in the amount of microorganisms was determined. The pollen collected by traps with thermo chambers had the highest number of microorganisms; however, it was not so high as compared to the pollen removed on the same day.

The highest amount of microorganisms was detected in the pollen stored in beehives for 48 hours. The total number of microorganisms in the pollen collected by different traps ranged from $5.0 \times 10^{3}$ to $19.3 \times$
$10^{3} \mathrm{cfug}^{-1}$. The average moisture content of the samples was $16.23 \%$. The pollen collected in high-bottom traps did not favour the development of microorganisms. The pollen stored for 48 hours in these traps had the lowest levels of microorganism contamination. The contamination of pollen collected in traps mounted at the hive entrance also increased insignificantly as compared to the pollen retained in traps for 24 hours. The pollen collected by traps with thermo chambers was the most contaminated with microorganisms. In this type of traps, the most significant increase in microorganism contamination was detected after 48 hours of retention in hives with the contamination reaching $19.3 \times 10^{3} \mathrm{cfu} \mathrm{g}^{-1}$. The proliferation of microorganisms was also more favoured in low-bottom traps. Compared to pollen stored in traps for 24 hours, contamination after 48 hours increased from $8.4 \times 10^{3}$ to $13.2 \times 10^{3} \mathrm{cfu} \mathrm{g}^{-1}$.

The impact of different pollen traps on the fungal contamination depending on the duration of pollen retention in traps is shown in Table 3. The lowest fungal contamination (18.5\%) was found in high-bottom traps. The pollen removed from traps mounted at the hive entrance after 9 and 48 hours had the highest fungal contamination, $30 \%$ and $29 \%$, respectively.

Table 3. Fungal contamination (\%) of the bee pollen collected by different traps

\begin{tabular}{lccc}
\hline \multicolumn{1}{c}{$\begin{array}{c}\text { Type of trap } \\
\text { (factor A) }\end{array}$} & \multicolumn{3}{c}{ Pollen retention period (factor B) } \\
\cline { 2 - 4 } & 9 hours & 24 hours & 48 hours \\
\hline High-bottom & $14.5 \mathrm{i}$ & $21.4 \mathrm{f}$ & $19.5 \mathrm{~g}$ \\
Low-bottom & $17.2 \mathrm{~h}$ & $24.2 \mathrm{e}$ & $25.0 \mathrm{de}$ \\
At hive entrance & $30.0 \mathrm{a}$ & $26.8 \mathrm{c}$ & $29.0 \mathrm{ab}$ \\
At hive entrance with a thermo chamber & $23.7 \mathrm{e}$ & $27.5 \mathrm{bc}$ & $26.5 \mathrm{~cd}$ \\
\hline
\end{tabular}

Note. Means not sharing common letters are significantly different at $P<0.05$.

During the studies, the most prevalent genera of fungi identified in bee pollen were Penicillium, Fusarium, Alternaria, Acremonium, Cladosporium, Mucor and Rhizopus (Tables 4-6). In addition to the dominant genera of fungi, the genera with a detection rate of $6 \%$ were isolated, namely the fungi of the Chaetomium, Paecilomyces, Aspergillus and yeast genera.

When analyzing the results of the pollen collected on the same day, it was found that of all the identified genera of fungi, the most common fungus in bee pollen was that of Penicillium genus $(65 \%)$. This genus in traps at the hive entrance and in traps with thermo chambers was the most widespread and accounted for $36 \%$ (Table 4 ). The Penicillium genus was less prevalent in the pollen collected in high-bottom and low-bottom traps - up to $13.8 \%$. The Fusarium fungi, as compared to the other identified genera, were also abundant $-10.3 \%$. This genus was the most frequent in the pollen collected by low-bottom traps and traps mounted at the hive entrance, accounting for $19.7 \%$ and $11.3 \%$, respectively. The pollen collected by low-bottom traps and traps with thermo chambers was found to have the lowest Fusarium sp. amounts of $5.0 \%$ and $5.8 \%$, respectively. The Alternaria genus was detected in $8.1 \%$ of the pollen. Comparing the types of traps, the highest amount of Alternaria sp. fungus was found in the pollen collected by traps mounted at the hive entrance, while the lowest amount was found in the pollen collected by traps with thermo chambers. The pollen contained some less common species of fungi: Acremonium and Cladosporium (both genera) accounted for $4.7 \%$, Mucor and Rhizopus - for $3.9 \%$ and $3.6 \%$, respectively.

After storing pollen for 24 hours in different traps, it was found that fungi in them had spread much more in comparison to the pollen removed after 9 hours (Table 3). If the total number of fungal colonies on the

Table 4. The number of microscopic fungi in the bee pollen after 9 hours' retention

\begin{tabular}{|c|c|c|c|c|c|c|c|}
\hline \multirow{2}{*}{ Type of trap } & \multicolumn{7}{|c|}{ Fungal genera cfu g ${ }^{-1}$} \\
\hline & Penicillium & Fusarium & Alternaria & Cladosporium & Mucor & Rhizopus & Acremonium \\
\hline High-bottom & $32 \mathrm{~b}$ & $3 \mathrm{~b}$ & $7 \mathrm{~b}$ & $7 \mathrm{a}$ & $5 \mathrm{a}$ & $0 \mathrm{~b}$ & $6 \mathrm{a}$ \\
\hline Low-bottom & $33 \mathrm{~b}$ & $14 \mathrm{a}$ & $7 \mathrm{~b}$ & $7 \mathrm{a}$ & $4 \mathrm{ab}$ & $6 \mathrm{a}$ & $0 \mathrm{~b}$ \\
\hline At hive entrance & $83 \mathrm{a}$ & $14 \mathrm{a}$ & $11 \mathrm{a}$ & $1 \mathrm{~b}$ & $3 \mathrm{bc}$ & $6 \mathrm{a}$ & $6 \mathrm{a}$ \\
\hline At hive entrance with a thermo chamber & $83 \mathrm{a}$ & $6 \mathrm{~b}$ & $4 \mathrm{c}$ & $2 b$ & $2 \mathrm{c}$ & $1 \mathrm{~b}$ & $5 \mathrm{a}$ \\
\hline
\end{tabular}

Note. Means not sharing common letters are significantly different at $P<0.05$. 
same day comprised 358 units $(21.4 \%)$, the number in different traps after 24 hours increased by 104 units $(24.9 \%)$.

The most favourable conditions were for the proliferation and spreading of the Penicillium genus with a prevalence of $57.8 \%$ (Table 5). The number of colonies found in the traps at the hive entrance and at entrance with a thermo chamber was 81 and 91 , respectively. The number of the Fusarium fungi in the pollen retained in hives for two days amounted to 69 units. A more significant increase was found in the pollen stored in low-bottom traps - by 13 units, the least - in traps at the entrance to hives - by 1 unit. The Cladosporium fungi accounted for $8.2 \%$ of the total number of identified fungal genera. The most noticeable increase was recorded in high-bottom traps - by 15 genera. The Mucor and Rhizopus sp. was determined in the pollen - the total number of colonies amounted to 31 and 23 units, respectively. The most favourable conditions for the proliferation of the Mucor fungi were in low-bottom traps, traps at hive entrance and traps with thermo chambers.

Table 5. The number of microscopic fungi in the bee pollen after 24 hours' retention

\begin{tabular}{lccccccc}
\hline \multicolumn{1}{c}{ Type of trap } & \multicolumn{6}{c}{ Fungal genera cfu g-1 $^{-1}$} \\
\cline { 2 - 8 } & Penicillium & Fusarium & Alternaria & Cladosporium & Mucor & Rhizopus & Acremonium \\
\hline High-bottom & $50 \mathrm{c}$ & $14 \mathrm{bc}$ & $2 \mathrm{c}$ & $22 \mathrm{a}$ & $3 \mathrm{c}$ & $3 \mathrm{c}$ & $5 \mathrm{~b}$ \\
Low-bottom & $45 \mathrm{~d}$ & $27 \mathrm{a}$ & $9 \mathrm{a}$ & $11 \mathrm{~b}$ & $11 \mathrm{a}$ & $8 \mathrm{a}$ & $1 \mathrm{c}$ \\
At hive entrance & $81 \mathrm{~b}$ & $15 \mathrm{~b}$ & $7 \mathrm{~b}$ & $3 \mathrm{c}$ & $9 \mathrm{~b}$ & $5 \mathrm{~b}$ & $4 \mathrm{a}$ \\
At hive entrance with a thermo chamber & $91 \mathrm{a}$ & $13 \mathrm{c}$ & $2 \mathrm{c}$ & $2 \mathrm{~d}$ & $8 \mathrm{~b}$ & $7 \mathrm{a}$ & $4 \mathrm{a}$ \\
\hline
\end{tabular}

Note. Means not sharing common letters are significantly different at $P<0.05$.

The pollen stored for 48 hours contained the highest total amount of the Penicillium sp., which accounted for $52 \%$ (Table 6). The total amounts of the Cladosporium sp., Rhizopus and Acremonium sp. did not increase.
The amounts of the Mucor and Alternaria fungi increased in all types of traps. The pollen removed after three days contained $13 \%$ of Mucor on average. More favourable conditions for the spread of fungi occurred in traps at the hive entrance and in low-bottom traps.

Table 6. The number of microscopic fungi in the bee pollen after 48 hours' retention

\begin{tabular}{|c|c|c|c|c|c|c|c|}
\hline \multirow{2}{*}{ Type of trap } & \multicolumn{7}{|c|}{ Fungal genera cfu g-1 } \\
\hline & Penicillium & Fusarium & Alternaria & Cladosporium & Mucor & Rhizopus & Acremonium \\
\hline High-bottom & $50 \mathrm{c}$ & $12 \mathrm{c}$ & $17 \mathrm{c}$ & $9 \mathrm{~b}$ & $11 \mathrm{c}$ & $2 \mathrm{a}$ & $0 \mathrm{c}$ \\
\hline Low-bottom & $53 \mathrm{c}$ & $22 \mathrm{a}$ & $21 \mathrm{~b}$ & $11 \mathrm{a}$ & $20 \mathrm{~b}$ & $0 \mathrm{c}$ & $2 \mathrm{a}$ \\
\hline At hive entrance & $77 \mathrm{~b}$ & $21 \mathrm{a}$ & $24 \mathrm{a}$ & $4 \mathrm{c}$ & $23 \mathrm{a}$ & $0 \mathrm{c}$ & $1 \mathrm{~b}$ \\
\hline At hive entrance with a thermo chamber & $89 \mathrm{a}$ & $15 \mathrm{~b}$ & $9 \mathrm{~d}$ & $10 \mathrm{ab}$ & $11 \mathrm{c}$ & $1 \mathrm{~b}$ & $2 \mathrm{a}$ \\
\hline
\end{tabular}

Note. Means not sharing common letters are significantly different at $P<0.05$.

The fungi of the Alternaria genus produced 71 units after 48 hours' retention in hives. The most abundant fungi of this genus were found in traps at the hive entrance as well as in high- and low-bottom traps.

\section{Discussion}

Pollen is highly hygroscopic. It can be exposed to high relative humidity environments which is typical of some beekeeping areas during flowering seasons (Gonzáles et al., 2005). Moisture content in the pollen varied from day to day in the study. On the first day of pollen collection and removal its moisture content was $22.6 \%$. Other researchers also reported similar results: 14.6-37.7\% (Nardoni et al., 2016) and 21-30\% (Bobis et al., 2010). Moisture content of the pollen in traps after 24 hours' storage decreased by $1.1 \%$, after 48 hours by $6.4 \%$. During the study period, the pollen with the highest moisture content was collected from low-bottom traps; the moisture content was $25.3 \%$. Low-bottom traps were installed inside hives and the pollen in them was less ventilated, thus it had the highest moisture content, whereas the pollen at the hive entrance had the lowest moisture content $16.1 \%$.

The lowest number of microorganisms (4.5-9.5 $\times 10^{-3}$ ) was recorded in the pollen removed from traps on the same day (after 9 hours), while the maximum contamination was found in the pollen stored in traps for three days (after 48 hours), ranging from 5.0 to $19.3 \times$ $10^{3} \mathrm{cfu} \mathrm{g}^{-1}$.

Penicillium, Fusarium and Alternaria sp. fungi dominated in the pollen; similar results were obtained with fresh pollen by Nardoni et al. (2016) and with dried pollen by Kačaniova et al. (2011). According to the mentioned authors, the recovery of fungi such as Penicillium sp. in trapped pollen presents a potential risk for human health and attention should be paid to all stages of the post-harvest process.

Fungal contamination in traps varied depending on their type. The lowest contamination of pollen by microbiota was found in high-bottom traps in the samples collected during all days of the study, while the highest one was in the traps with thermo chambers.

The pollen collected by high-bottom traps showed the lowest level of contamination by microorganisms and depending on different storage periods in hives, ranged from 4.5 to $5.0 \times 10^{3} \mathrm{cfu} \mathrm{g}^{-1}$. Traps of this type are installed high from the bottom of the hive, where pollen is better ventilated; there is less dust, which could adversely affect the development of both bacteria and fungi. A comparatively small number of colonies of microorganisms were found in the pollen collected in traps mounted at the hive entrance.

The highest number of microorganism colonies $\left(9.5-19.3 \times 10^{3} \mathrm{cfu}^{-1}\right)$ was found in traps with thermo 
chambers which used solar energy to further dry out pollen. Toxic fungi are divided into field and storage ones (Logrieco, Visconti, 2004). With reduced pollen moisture content, favourable conditions were created for the spreading of both field and storage fungi. The highest amount of the Penicillium sp. fungi was found in this type of traps, as compared to other types, on all days of the study. Penicillium sp. in the pollen removed from these traps on the same day after 24 and 48 hours accounted for $80.6,71.7$ and $65 \%$, respectively. Compared to the total number of identified genera of fungi, contamination of the pollen by this fungus was also the highest. The studies conducted by Gonzáles et al. (2005) and Finola et al. (2007) also confirmed that the fungi of the genus Penicillium were dominant in pollen. Although the Penicillium genus is one of the most commonly encountered in stored products, it can often be found as the field fungus under favourable conditions for its spread. Moisture content of the substrate (Lacey, Magan, 1991) has a significant influence on its spread. Leistner (1984) reported a study dealing with toxinogenic Penicillium $\mathrm{sp}$. in food. Penicillium sp. isolates determined in food-related habitats should be considered as potential mycotoxin producers according to this author.

The Fusarium fungi were found most frequently in pollen collected by low bottom traps during all the days of the study. The spread of the Fusarium sp. fungi requires a substrate containing about $60 \%$ of the available water (Llorens et al., 2004). Traps installed at the bottom of hives could have influenced the abundance of this genus. Fusarium is the main toxin producing genus of the field fungi (Logrieco, Visconti, 2004). Fusarium sp., unlike Penicillium sp. whose presence requires attention in all stages of pollen storage and processing, is not significant at these stages (Nardoni et al., 2016). However, improperly dried and stored for prolonged period pollen may provide favourable conditions for the growth of Fusarium sp. and the synthesis of mycotoxins. A similar trend is observed in this study.

Alternaria sp. prevalence in the pollen was not high. This genus was the most abundant in traps at the hive entrance and in low-bottom traps. Kačaniova et al. (2011) found that Alternaria sp. is a common genus found in honey. The Cladosporium genus in pollen did not spread extensively, although in Nardoni et al. (2016) studies Cladosporium sp. was the most frequently recovered mold.

The lowest amounts of the Mucor sp. fungi were found in the pollen removed on the same day. Fungal contamination of the pollen stored in traps for 24 and 48 hours was the highest in traps at the hive entrance and in low-bottom traps. These results were opposite to the research data by Kačaniova et al. (2011), where the genus Mucor was recorded as one of the most frequent isolates.

This study was focused on the determination of fresh pollen contamination by fungi depending on the type of traps and pollen retention duration in them. The studies showed that the amount of fungi in the pollen was dependent on the type of traps.

The fungal composition isolated from bee pollen showed that the Penicillium, Alternaria and Fusarium are the most common genera. These genera are capable of producing toxins, which can adversely affect the quality of this exceptional and therapeutic product under favourable conditions (Kačaniova et al., 2011; Rodríguez-Carrasco et al., 2013). One of the primary means of reducing contamination by microorganisms is the choice of the appropriate type of pollen traps.

\section{Conclusions}

1. The lowest contamination $\left(6.7 \times 10^{3} \mathrm{cfu} \mathrm{g}^{-1}\right)$ of fresh bee pollen by microorganisms was determined after 9 hours of its removal from traps.

2. The study showed that pollen collected in high-bottom traps had the lowest levels $\left(4.8 \times 10^{3} \mathrm{cfu} \mathrm{g}^{-1)}\right.$ of contamination by microorganisms, while the highest contamination $\left(12.8 \times 10^{3} \mathrm{cfu} \mathrm{g}^{-1}\right)$ was in the traps with thermo chambers.

3. Fungal contamination was the higest in the bee pollen collected by traps mounted at the hives entrance after 9 and 48 hours -124 and 150 units, respectively.

4. Moisture content of fresh pollen was favourable for the growth and spread of microorganisms. The highest moisture content was in the pollen collected from low-bottom traps, whereas pollen at the entrance to hives was the driest. Therefore, in order to prevent the activity of microorganisms, pollen removed from traps must be dried as soon as possible.

Received 13042019

Accepted 27092019

\section{References}

1. Bobis O., Marghitas I., A., Dezmirean D., Morar O., Bonta V., Chirila F. 2010. Quality parameters and nutritional value of different commercial bee products. Bulletin of University of Agricultural Sciences and Veterinary Medicina Cluj-Napoca. Animal Science and Biotechnologies, 67: 1-2.

2. Brindza J., Grof J., Bacigalova K., Ferianc P., Toth D. 2010. Pollen microbial colonization and food safety. Acta Chimica Slovaca, 3 (1): 95-102.

3. Deveza M. V., Keller K. M., Lorenzon M. C. A., Nunes I. M. T., Sales E. O., Bart O. 2015. Mycotoxicological and palynological profiles of commercial brands of dried bee pollen. Brazilian Journal of Microbiology, 46 (4): $1171-1176$

https://doi.org/10.1590/S1517-838246420140316

4. Estevinho M. L., Afonso S. E., Feas X. 2011. Antifungal effect of lavender honey against Candida albicans, Candida crusei and Cryptococcus neuformans. Journal of Food Science and Technology, 48 (5): 640-643. https://doi.org/10.1007/s13197-011-0243-1

5. Finola M. S., Lasagno M. C., Marioli J. M. 2007. Microbiological and chemical characterization of honeys from central Argentina. Food Chemistry, 100 (4): 1649-1653. https://doi.org/10.1016/j.foodchem.2005.12.046

6. Garcia-Villanova R. J., Cordón C., GonzálezParamás A. M., Aparicio P., Garcia Rosales M. E. 2004. Simultaneous immunoaffinity column cleanup and HPLC analysis of aflatoxins and ochratoxin A in Spanish bee pollen. Journal of Agricultural and Food Chemistry, 52 (24): 7235-7239. https://doi.org/10.1021/jf048882z

7. González G., Hinojo M. J., Mateo R., Medina A., Jiménez M. 2005. Occurrence of mycotoxin producing fungi in bee pollen. International Journal of Food Microbiology, 105 (1): 1-9.

https://doi.org/10.1016/j.ijfoodmicro.2005.05.001

8. Jay J. M. 2007. Modern food microbiology. Aspen Publishers, USA, $617 \mathrm{p}$.

9. Kačaniova M., Juraček M., Chlebo R., Knazovicka V., Kadasi-Horakova M., Kunova S., Lejkova J., Haščik P., Mareček J., Šimko M. 2011. Mycobiota and mycotoxins in bee pollen collected from different areas of Slovakia. Journal of Environmental Science and Health, 46 (7): 623-629.

https://doi.org/10.1080/03601234.2011.589322 
10. Kieliszek M., Piwowarek K., Kot M. A., Blažejak S., Chlebowska-Smigiel A., Wolska I. 2018. Pollen and bee bread as new healt-oriented products. Trends in Food Science and Technology, 71: 170-180. https://doi.org/10.1016/j.tifs.2017.10.021

11. Lacey J., Magan N. 1991. Fungi in cereal grain: their occurrence and water and temperature relations. Chelkowski J. (ed.). Cereal grain. Mycotoxins, fungi and quality in drying and storage. Elsevier, p. 77-118.

12. Leistner L. 1984. Toxinogenic penicillia occurring in feeds and foods: a review. Food Technology in Australia, 36: 404-413.

13. Llorens A., Mateo R., Hinojo M., Jimenez M. 2004. Influence of environmental factors on the biosynthesis of type B trichothecenes by isolates of Fusarium spp. from Spanish crops. International Journal of Food Microbiology, 94 (1): 43-54. https://doi.org/10.1016/j.ijfoodmicro.2003.12.017

14. Logrieco A., Visconti A. (eds). 2004. An overview on toxigenic fungi and mycotoxins in Europe. Vol. 1. Kluwer Academic Publishers, $252 \mathrm{p}$. https://doi.org/10.1007/978-1-4020-2646-1

15. Medina A., González G., Sáez J. M., Mateo R., Jiménez M. 2004. Bee pollen, a substrate that stimulates ochratoxin A production by Aspergillus ochraceus Wilh. Systematic and Applied Microbiology, 27 (2): 261-267.

https://doi.org/10.1078/072320204322881880
16. Nardoni S., D’Ascenzi C., Rocchigiani G., Moretti V., Mancianti F. 2016. Occurrence of moulds from bee pollen in Central Italy - a preliminary study. Annals of Agricultural and Environmental Medicine, 23 (1): 103-105. https://doi.org/10.5604/12321966.1196862

17. Petrovic T., Nedic N., Paunovic D., Rajic J., Matovic K., Radulovic V., Krnjaja V. 2014. Natural mycobiota and aflatoxin B1 presence in bee pollen collected in Serbia. Biotechnology in Animal Husbandry, 30 (4): 731-741. https://doi.org/10.2298/BAH1404731P

18. Pitt J. I., Hocking A. D. 2009. Fungi and food spoilage. Springer, $519 \mathrm{p}$. https://doi.org/10.1007/978-0-387-92207-2

19. Popa M., Vica M., Axinte R., Glevitzky M., Varvara S. 2009. Study concerning the honey qualities in Transylvania region. Annales Universititas Apulensis Series Oeconomica, 11 (2): 1034-1040.

20. Raudonius S. 2017. Application of statistics in plant and crop research: important issees. Zemdirbyste-Agriculture, 104 (4): 377-382. https://doi.org/10.13080/z-a.2017.104.048

21. Rodríguez-Carrasco Y., Font G., Mañes J., Berrada H. 2013. Determination of mycotoxins in bee pollen by gas chromatography-tandem mass spectrometry. Journal of Agricultural and Food Chemistry, 61 (8): 1999-2005. https://doi.org/10.1021/jf400256f

22. Whitefield F. B. 1998. Microbiology of food taints. International Journal of Food Science and Technology, 33 (1): 31-51. https://doi.org/10.1046/j.1365-2621.1998.00156.x

ISSN 1392-3196 / e-ISSN 2335-8947

Zemdirbyste-Agriculture, vol. 106, No. 4 (2019), p. 377-382

DOI $10.13080 /$ z-a.2019.106.048

\title{
Skirtingo tipo rinktuvais surinktų bičių žiedadulkių mikobiota
}

\author{
J. Sinkevičienè, A. Amšiejus \\ Vytauto Didžiojo universiteto Žemès ūkio akademija
}

\begin{abstract}
Santrauka
Nešimo dieną žiedadulkių neišėmus iš rinktuvų, kyla jų mikrobiologinės taršos grèsmè. Trūksta tyrimų ne tik apie pradinę šviežiu žiedadulkių mikrobiologinę taršą, kuriai gali turèti įtakos skirtingų tipų žiedadulkių rinktuvai, bet ir apie žiedadulkių saugiausią laikymo trukmę rinktuvuose.

Tyrimo tikslas - nustatyti skirtingų rinktuvų įtaką žiedadulkių mikrobiologinei taršai, priklausomai nuo jų laikymo rinktuvuose trukmès. 2018 m. ištirti 96 bičių žiedadulkių mėginiai. Mikroorganizmų pradų kiekis žiedadulkèse tyrimo laikotarpiu kito nuo 4,5 iki 19,3 $\times 10^{3} \mathrm{ksv}$ (kolonijas sudarančių vienetų) $\mathrm{g}^{-1}$. Žiedadulkèse nustatytas drègmės kiekis buvo optimalus mikroskopiniams grybams augti ir daugintis. Žiedadulkèse buvo nustatytos dažniausiai vyravusios 7 grybų gentys: Penicillium, Fusarium, Alternaria, Acremonium, Cladosporium, Mucor ir Rhizopus. Ištyrus keturiais skirtingais rinktuvais surinktų žiedadulkių mikrobiotą nustatyta, kad bendras mikroorganizmu kiekis kito priklausomai nuo rinktuvo tipo ir žiedadulkių buvimo avilyje trukmès. Žiedadulkių rinkimo dienos pabaigoje (po 9 val.) iš rinktuvų išimtos žiedadulkès pasižymėjo mažiausia mikrobiologine tarša. Mikroorganizmų pradų kiekis buvo mažiausias $\left(4,5 \times 10^{3} \mathrm{ksv} \mathrm{g}^{-1}\right)$ aukšto dugno rinktuvuose. Visuose tyrimo variantuose didžiausia žiedadulkių mikrobiotos tarša nustatyta 48 valandas laikytose žiedadulkèse. Per tris tyrimo dienas surinktuose mėginiuose žiedadulkių mažiausia tarša $\left(4,8 \times 10^{3} \mathrm{ksv} \mathrm{g}^{-1}\right)$ mikroorganizmais nustatyta aukšto dugno rinktuvuose, didžiausia $\left(12,8 \times 10^{3} \mathrm{ksv} \mathrm{g}^{-1}\right)$ - rinktuvuose su termokameromis. Mikroskopinių grybų didžiausi kiekiai nustatyti žiedadulkèse, surinktose prieš avilio laka ịrengtuose rinktuvuose po 9 ir 48 val. -124 ir 150 vnt. Penicillium genties grybai dominavo žiedadulkèse, surinktose rinktuvais su termokamera, Fusarium - žemo dugno, Alternaria - prieš avilio laką ịrengtais rinktuvais surinktose žiedadulkèse.
\end{abstract}

Reikšminiai žodžiai: bičių žiedadulkès, grybai, mikroorganizmai, tarša, žiedadulkių rinktuvai. 